\title{
Hydrocarbon Potential of the South-Western Part of the Cauto Basin, Cuba
}

\author{
Mu'awiya B. Aminu, Changde A. Nanfa, Zulaihat J. Sanni, Simon D. Christopher, Ahmad T. Dahiru, \\ Habeeb A. Ayoola, and Godwin O. Aigbadon
}

\section{ABSTRACT}

The "Assessment of the southwestern of the Cauto Basin and its oil and Gas possibilities in Cuba" was carried out with the objective of evaluating the southwestern part of the Cauto Basin in Cuba from the geological and geophysical point of view, with the southwestern of the Basin as a foundation of the petroleum system models. The method of investigation employed included interpretation of the seismic lines, the surface geology, the well logging data, gravimetric and magnetometrics data. The research was developed in three fundamental stages: I) Preliminary stage, II) Data processing and III) Interpretation of results/conclusions and recommendations. The characterization of sedimentary structures was assessed, and the evolution of the studied basin was also realized. Based on the result of this study, the origin of Cauto Basin can be linked to the geological event that occurred in the area towards the end of the Cretaceous era which involves complex sedimentary processes with associated collusions and extension of tectonic transcurrente. This leads to formation of Delta zones and important fans, which were the product of rapid sedimentation and slow subsidence. Furthermore, the result reveals that the studied interval can be described as a potential reservoir for being part of the fan and deltaic zone. There is evidence of the presence of hydrocarbon within the studied interval, but probing further depth has the potential of more discovery within the source rock since only the Tertiary reservoirs were evaluated.

Keywords: Cauto Basin; Delta; Fans; Hydrocarbon; Rapid sedimentation; Seismic lines; Source rock.
Published Online: January 30, 2022

ISSN: $2684-446 \mathrm{X}$

DOI :10.24018/ejgeo.2022.3.1.242

\section{M.B. Aminu*}

Department of Geology, Faculty of Sciences, Federal University Lokoja, Kogi State, Nigeria.

(e-mail: muawiya.babaaminu@fulokoja.edu.ng C.A Nanfa

Department of Geology, Faculty of Sciences, Federal University Lokoja, Kogi State, Nigeria.

(e-mail: Nanfa.changde@fulokoja.edu.ng)

Z.J. Sanni

Department of Geology, Faculty of Sciences, Federal University Lokoja, Kogi State, Nigeria.

(e-mail: zulaihat.sanni@fulokoja.edu.ng)

S.D. Christopher

Department of Geology, Faculty of Sciences, Federal University Lokoja, Kogi State, Nigeria.

(e-mail: simon.christopher@fulokoja.edu.ng) A.T Dahiru

Department of Geology, School of Science. Zamfara College of Arts and Science, Gusau, Zamfara State, Nigeria.

(e-mail: dahiruahmadtijjani@gmail.com)

H.A Ayinla

Department of Geology, Faculty of Sciences, Federal University Lokoja, Kogi State, Nigeria.

(e-mail: Habeeb.ayinla@fulokoja.edu.ng)

G.O. Aigbadon Department of Geology, Faculty of Sciences, Federal University Lokoja, Kogi State, Nigeria.

(e-mail: godwin.aigbadon@fulokoja.edu.ng)

*Corresponding Author

\section{INTRODUCTION}

Hydrocarbons are the fundamental source for generating energy worldwide. In the midst of the economic crisis, it high prices caused any product in the world market to keep prices totally unstable, always oscillating at astronomical values. That is why one of the solutions to face this crisis, in a country like Cuba, is to summarize and look into the substitution of imports and local production of hydrocarbons. To ensure that national production meets the needs and to locate new hydrocarbon deposits that increase reserves and production; the current research is to be aimed at studying new basins to evaluate their Oil-Gas possibilities and to deepen the studies of basins that have already been evaluated. Like the case study at hand.

The study area, the South-Western area of the Cauto Basin, was selected for the investigation due to the geological and geophysical properties found in this area, which cover the basin research period from the last century to date.

In order to facilitate geological and geophysical interpretation, a map showing surface geological observations, combined with geophysical and structural maps from the same area have been used. The interpretation may then need to be overlaid on a land use map to examine access details, or on the map of an existing drill hole to 
determine whether the previous exploration had been carried out on the area.

\section{PhysicAl-GeOGRAPHICAL AND GEOLOGICAL CHARACTERISTICS}

\section{A. Geological Settings}

Physical-geographical and geological characteristics of the study area.

\section{B. Geographical location}

Physical-geographical characteristics of the study area were described at the Cauto Basin in Cuba.

The study area is located in the South of Eastern Cuba, being one of the largest areas of Cuba, its length is $170 \mathrm{~km}$, with a width of $35-80 \mathrm{~km}$, occupying an approximate area of $4200 \mathrm{~km}^{2}$ on land and the other part is insular. The Cauto Basin is located between the province of Holguín and the province of Granma, extending south towards the Gulf of Guacanayabo. The study area is located in the southsouthwest zone of the designated basin, limited by the coordinate $76^{\circ} 35^{\prime \prime}$ and $70^{\circ} 50^{\prime \prime}$ North Latitude and $150^{\circ} 50^{\prime \prime}$ and $200^{\circ} 35^{\prime \prime}$ West Longitude. According to Lambert's conformal projection, it has as its coordination: X: 74497228701291; Y: 3821650-3993022.
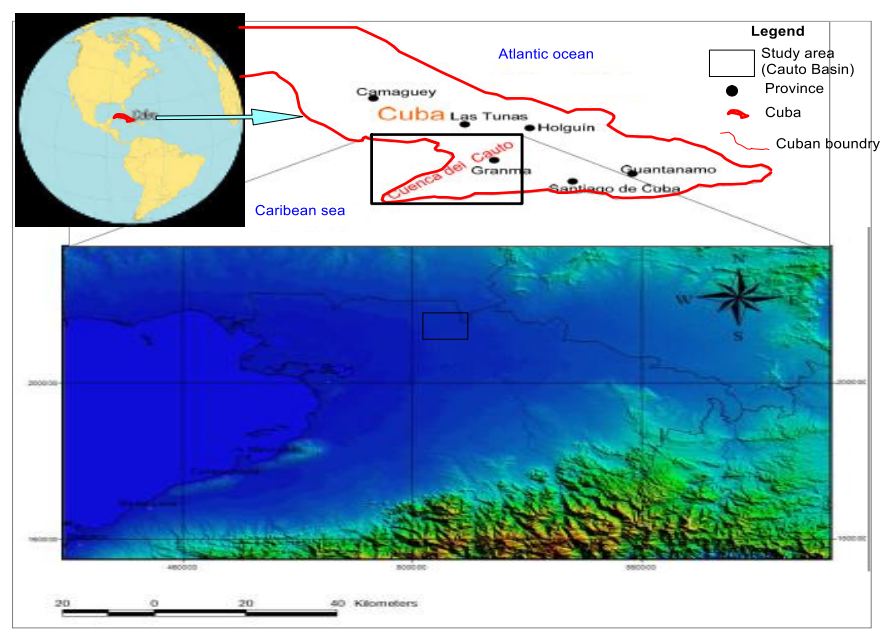

Fig. 1. Map of Geographical location of the study area (Modified after [1]).

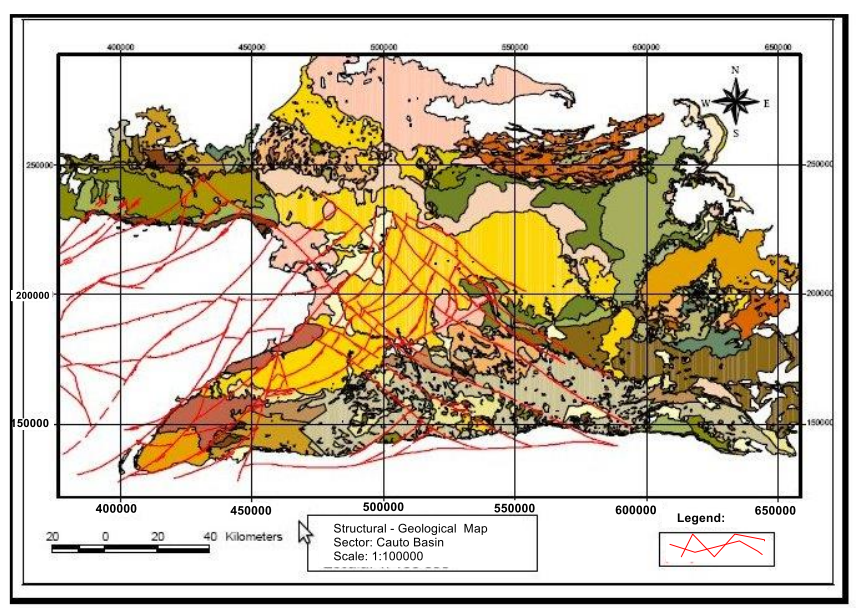

Fig. 2. Structural Geological Map of the Cauto Basin (Modified after Garcia, [2]).

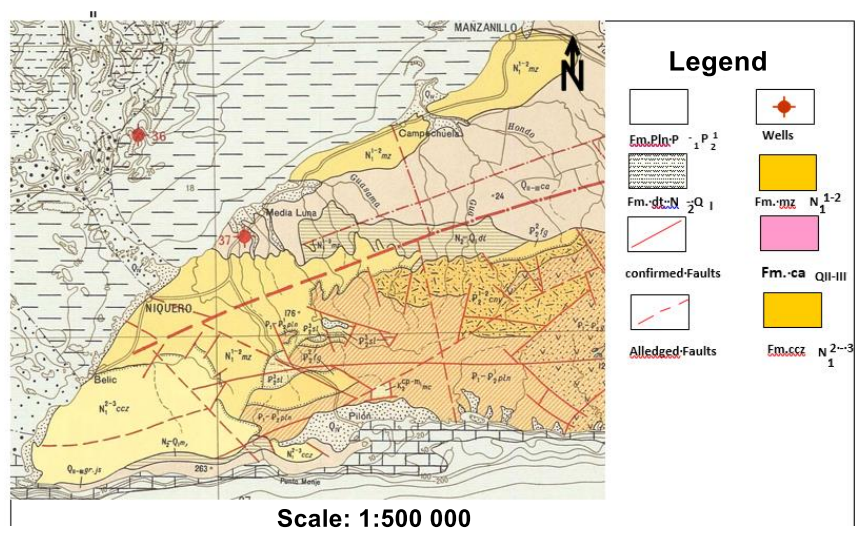

Fig. 3. Structural Geological Map of the Cauto Basin (Modified after [2]).

\section{MATERIALS AND METHODS}

A research methodology was developed which allows the use of available data (Fig. 4).

It has been processed through the compilation of various research methodologies, Basin analysis researches in an integrated way to geology and geophysics were reviewed as grab tools with the uses of computer software during the interpretation of seismic lines and stratigraphic drilled wells data.

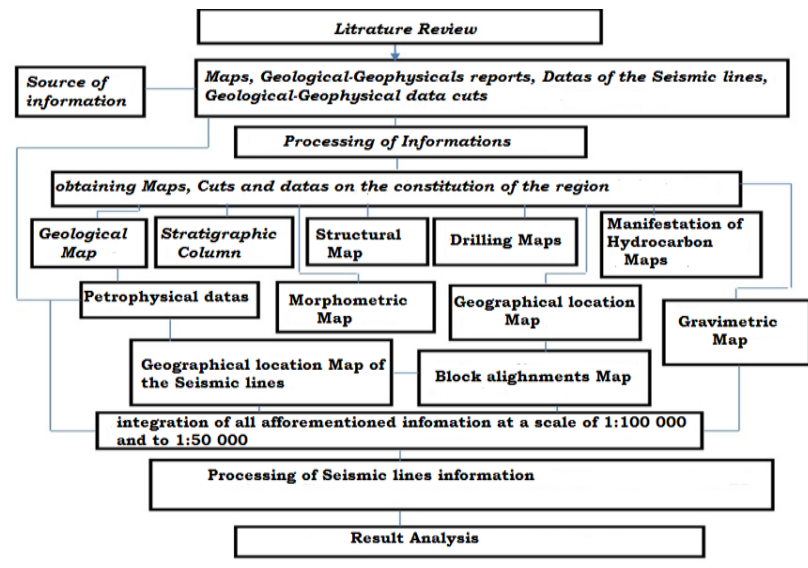

Fig. 4. Workflow chart adopted for this research.

The processing and analysis of the data of the geophysical methods in a systemic way were oriented to the tectonic regionalization and the study of the deep geological constitution of the territories, these must include three stages:

\section{1) Bibliographic review (collection of existing information)}

A bibliographic review of the researches that have been carried out and conducted in the Cauto Basin, related to the objective of the study, updated literature on seismic interpretation, especially the researches dedicated to the earthquake stratigraphy has been collected.

The literature review allows regrouping the relevant information in the regional and local geology, which involves works and researches related to the region of Eastern Cuba and particularly the development of the Cauto Basin. Consulted bibliographies on tectonics and sedimentology, methodological and conceptual works of 
tectonic evolution, and facies analysis were also reviewed and selected.

\section{2) Processing of information}

Eight (8) seismic sections were processed, approximately transverse to the study area (Fig. 19), using seismic stratigraphy as a method of processing and interpretation. The drilled wells of the area were used to calibrate the seismic lines, confronting their depths in time with the real depth reached by the wells; 16 deep wells have been drilled in the Cauto basin area, all these wells, with the exception of Granma, were drilled in the decade of the 1950s by different North American companies. In some wells (Rabihorcado and Macaca), they carried out differential (acoustic) seismocarotage research [3], [4].

Also, of significant methodological and practical value is the integrated use of the information of the regional geological map of Eastern Cuba with the scale of 1:500 000, together with the data from the stratigraphic lexicon to define ages, depositional paleoenvironment, and the geological reinterpretation of the gravimetric maps and magnetics.

Based on the analysis of the existing information, maps of the study area are prepared using different Computer Applications e.g., Surfer Version 10 and 11, AutoCAD 2009, AutoDesk DWF.

1. AutoCAD was to establish the location of the seismic line and their position with respect to the drilled wells.

2. AutoDesk DWF: was used for displaying the images, (Fig. 5).

3. Sufer 9, 10 and 11: for processing and interpretation of seismic lines (Fig. 6).

4. Paint: for image processing.

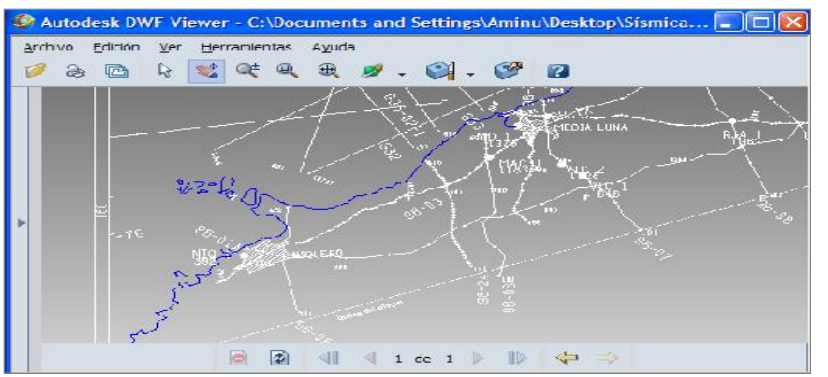

Fig. 5. AutoDesk DWF: for viewing images.

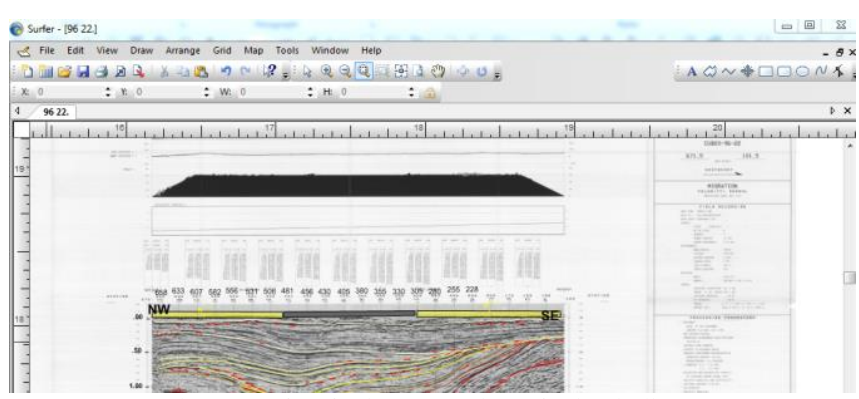

Fig. 6. Surfer: for interpretation of seismic lines.

\section{3) Interpretation of results / conclusions and} recommendations

The five (5) perforations (drilled wells) in the NorthwestSouthwest direction profile of the Cauto basin coincide with the seismic profiles and are covered by magnetometrics and gravimetric investigations. The information collected allows the sector to be generalized and compared it by analogy with other areas of the basin in the future. the maps available on the scale referred to below were digitized with $2 \mathrm{mGal}$ sampling interval between isolines for data gravimetric and in the case of magnetometrics it is $50 \mathrm{nT}$, which is adequate for its interpretations.

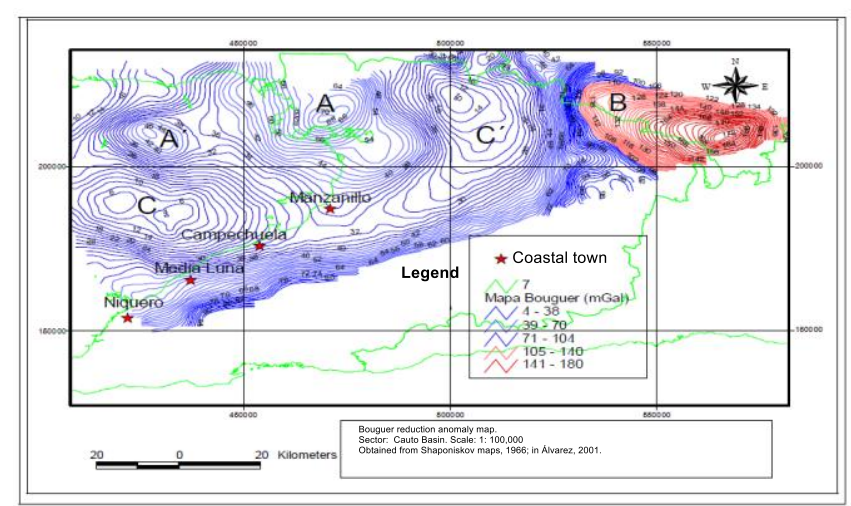

Fig. 7. Bouguer Reduction Anomaly Unified Map of the Cauto Basin (taken in [1])

Fig. 7 and 8 are an example of the result of this work stage. The map of the gravitational field and the result of its digitization are compared, appreciating the fidelity that the image features preserve, which results from being of utmost importance at this stage of the work.

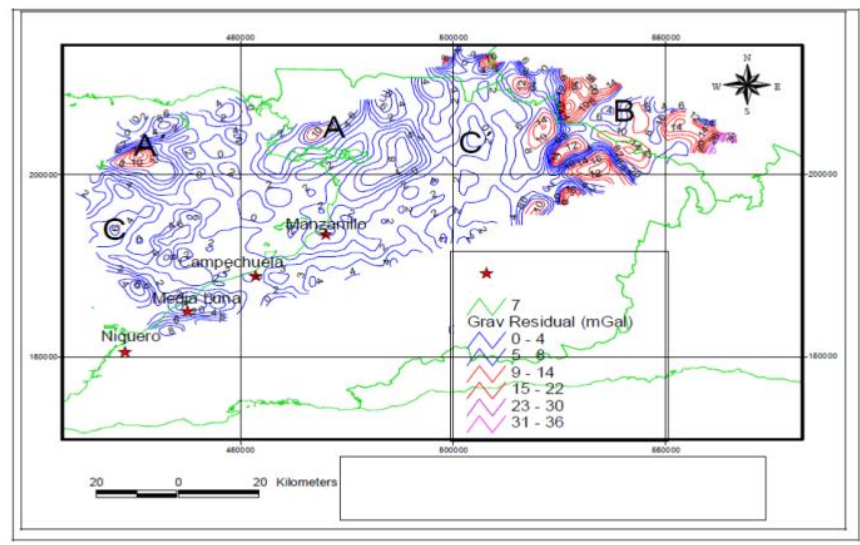

Fig. 8. Map of the residual anomalies of the gravimetric field. Sector: Cuenca del Cauto. Scale: 1: 100,000 (Modified after [5]).

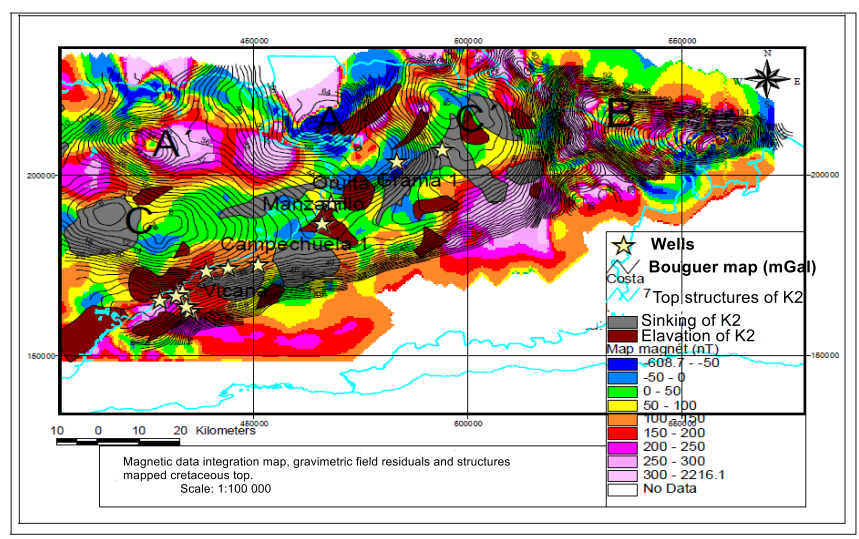

Fig. 9. Map of the magnetic data integration, gravimetric field residuals and the mapped structures associated with the top from the Upper Cretaceous (Modified from [1]. 


\section{RESUlTS AND DisCUSSION}

At the regional level, the integrated analysis allows the information to be combined, validated, and directed to obtain geological models at low costs; oriented to know the constitution of the object of study and to be located the areas of greatest interest for Hydrocarbon prospecting.

These models define the different scenarios and allow the creation of the exploration achievement strategy. Also, with the graphical representation of the parameters of location, distribution, shape, and internal variations of the lithological elements and possible presence of fluids in the study area, the chronostratigraphic units and sedimentation cycles are identified and interpreted.

\section{A. Interpretation of the Generalized Lithostratigraphic Column of the Cauto Basin}

The generalized lithostratigraphic column is prepared taking into account the different ages and the space-time position of the sedimentary sequences that make up the sedimentary fill of the Cauto Basin (Fig. 10). Its precision allows define the environments, distribution, and quality of the deposits of the sedimentary units, the lateral limits and the vertical barriers and in the lithology studied from the correlation.

Integrating the stratigraphic sequences in the directions through which the seismic lines of Block 20, drilling well data and surface geology were executed, stratigraphic sequences are defined, ranging from the basin basement to the Quaternary sediments were organized as follows:

\section{1) Upper Cretaceous sequences}

It emerges in parts of the basin and is represented by the Babiney Formation, of Maastrichtian age at Paleocene, has predominantly siliciclastic, siliciclastic-carbonated and thiogenic composition; It has not been cut by perforations, but it is well recorded in seismic lines. Its facies are fundamentally siliciclastic with gradual change to carbonates in its highest part (Maastrichtian). They are discordantly covered by tertiary sequences, their stops, and contacts in the raised areas of the linear folding that is recognized in seismic profiles and gravimetric studies is an important environment for hydrocarbon accumulations if its analogy with the Central Basin of Cuba in the province of Ciego de Ávila (Fig. 10).

\section{2) Middle Eocene sequences}

It is present in all wells in the area, like the Farallón Grande $\quad\left(\mathbf{P}_{2}{ }^{2 \mathbf{b}}\right)$ formations (polymorphic gaps, conglomerates, limestone shallow sandstones) and Barranca; $\left(\mathbf{P}_{2}{ }^{2 \mathbf{b}-3}\right)$ (crystallovitrocytic rhoditic-riodacitic tuffs), present with lateral changes towards the interior of the basin with more clayey facies. It is perfectly recognized in the profile and corresponds to the Crescent $1 \mathrm{X}$ well where it is identified as a deep-water slide, characterized by the mixture of planktonic and benthic foraminifera found in its paleontological record.

\section{3) Oligocene sequences}

It is represented by the formations of Sevilla Arriba, Fm. Camazán, Fm. Bitirí Dátil. In general, these rocks are fundamentally Limestone, Loam, and alluvial and marshy sediments, are not deformed, and correspond to some relatively quiet basin deposits. it is represented by the Paso Real Formations (Limestones, Calcarenite Dolomites, Marls, Sandstones, Limolites and Clays, Conglomerates at the base), Cabo Cruz (Clay biodetritic limestones, fossiliferous, marls, pseudoconglomerates), Manzanillo (clay biodetritic limestone), Río Maya (limolites, sandstones, shales, calcarenites and clays), Dátil (boulders deposits, blocks of pebbles of silicites, polymetric clay sands) and Bayamo (sands of fine grains, sandstones and conglomerates, sandy clays and clay sands).

\section{4) Carbonated facies}

Vertical and horizontal facial changes were observed, governed by differences in the tectonic processes but with a predominance of carbonated facies. Intrusive volcanic facies are referred to as the Formation El Cobre, represented by lava and pyroclastic rocks of predominantly andesitic and basaltic composition. Another author [7] affirmed that the Formation El Cobre, is represented by a paragenesis of very complete rocks in the quality of the predominant volcanic products over the sediments.

Lithological composition of these units was described in the deep wells; it is observed that the sequences belong to the time span of the development of the Paleogenic volcanic arc; with a predominance of the terrified-carbonated sequences on the vulcanogens, confirming statements by [8] where he declares the importance of the tuffs in the cut of the El Cobre group on sedimentary rocks.

The electrofacies are shown with positive Gamma Spontaneous Potential values from medium to high, the resistivity with low values, although intervals with collecting characteristics can be isolated, with negative spontaneous potential, increase in resistivity and neutron and decrease in gamma values. These intervals coincide with the bioclassic and conglomerated Packstonegrainstone, located in the Manzanillo 1 (670-762 m), Oruíta 1 (1370-1558 m.), Embarcadero 1 (800-900 m.), And Granma 1 (1025-1160 m.) in cores 6.7, and 8, with an average porosity of $14.53 \%$ In the nucleus 8 (1147-1148 m) of the Granma 1 well, the carbonated facies contain acid and basic effusive clastics, silty-sandy fraction of quartz, from the destruction of the arch.

The thicknesses in the study area where It is widely distributed, reach the highest ranges (greater than $750 \mathrm{~m}$ ), in the Embarcadero 1 well, and the Bahía (NW) Wells and smaller thicknesses in the Vicana 1 and Macaca 1 wells. It is assumed that the basin in this period was sinking and had a more elevated area to the south, which is the source of contribution of siliciclastic materials that are part of the sand and conglomerates. (Volcanic arch).

The changes in seismic velocity are related to the variations in the lithological composition, as well as to the porosity and types of fluids (liquid or gaseous): Reservoirs with a better petrophysical condition (more porous, more cracked, with less matrix and cement) usually register lower speeds. The fluids, the less dense, give lower seismic velocity values [9]. 


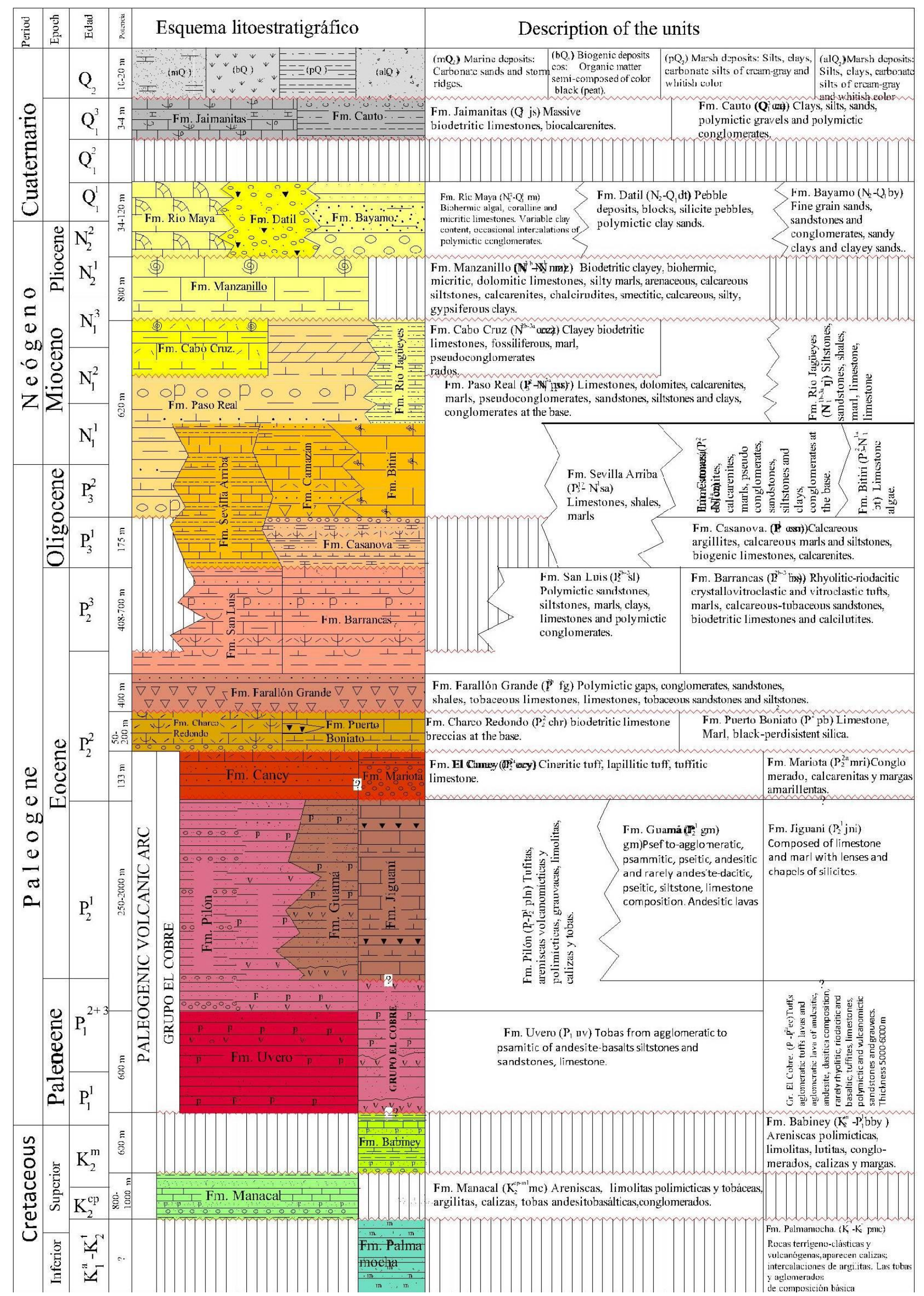




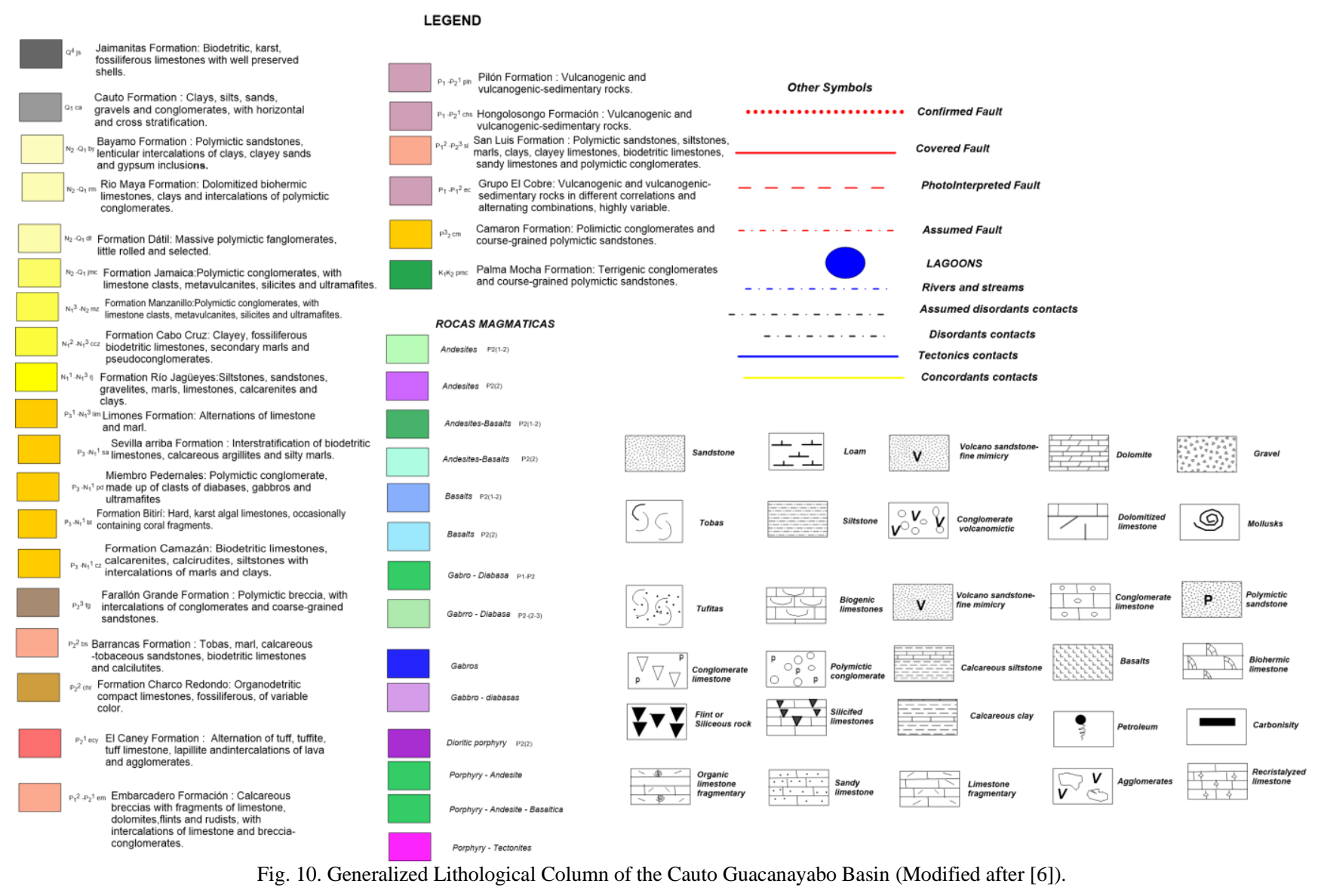

\section{5) Shallow and deep facies}

Although the K / T limit is marked throughout the world by a fine bed of clays enriched in iridium; In the Caribbean, it is found forming an arc of a circle of $3000 \mathrm{~km}$ from Alabama to Guatemala, Haiti, Western Cuba, formed by a layer of thick sand with a thickness between 2 or 3 meters with glass droplets and colliding minerals. Towards Eastern Cuba there are flyshoid and olistostromic sequences correlatable with the sequences that mark the $\mathrm{K} / \mathrm{T}$ limit in Western Cuba. At this limit, very important palaeogeographic changes occurred in the Caribbean area, when volcanic activity ceased, developing numerous marine basins of varying depths where carbonate terrigenous sequences accumulated, sometimes very fossiliferous.

The occurrence of a gradual passage between the $\mathrm{El}$ Cobre Group and the Charco Redondo and Puerto Boniato formations, composed of carbonate facies, accumulated in complex reefs and deep seas, effectively indicate a transcendental change in the regional geodynamic framework that gave rise to a process of accretion of eastern Cuba to the Bahamas paleoplatform, and where an obduction process was taking place that culminated in the thrust of all the structure riding on the Bahamas margin.

In the Lower Eocene-Middle Eocene limit, momentous changes occurred at the regional level that led to the cessation of volcanic subduction, producing the extinction of the Sierra Maestra volcanic island arc; due to the formation of the current, which transformed the boundary between the Caribbean and North American plates, which led to the gradual separation of Eastern Cuba from the Caribbean Plate and the abortion of the extension process that was taking place in the Cauto-Nipe Basin. This limit is characterized by the presence of two large facial assemblages: the lower one composed of sedimentary volcanic facies; and the upper one made up of carbonate facies. These facies present transitional vertical relationships.

The cessation of volcanic activity at the closure of the Lower Eocene, due to the collision with the Bahamas and the extension of the transforming boundary in the Bartlett Trench, was simultaneous with a process of increasing deformation of Eastern Cuba, resulting in the formation of two basins: a shallow one towards the south, where vulcanogenic molasses (Cauto Basin) accumulated, and a deeper one towards the north where the flyschoid deposits of tuffs with fine grains predominate, largely zeolitized. The presence of calcareous sediments and radiolarite facies in this group is very limited.

From the Early Middle Eocene, carbonated facies collected in reef complexes (especially to the south of Eastern Cuba) and to the north carbonated facies of rich deep seas with a varied planktonic microfauna.

\section{6) Tectono-Stratigraphic Evolution of the Basin}

The bed rock of the basin, which has not been cut by any well, is occupied by the rocks of the Cretaceous Volcanic Arch with its age cover (Campaniano-Maastrichtian) of siliciclastic-carbonated composition, which emerges to the south of the Sierra and in the region from the Silantro River; although there are isolated outcrops to the north of the Sierra in the region of Palma del Perro and on the road from Los Callejones to La Pimienta south of Guisa, where they emerge below the Charco Redondo Formation. These rocks are made up of dark gray micrites, fetid and massive. Towards the eastern center of the Basin there are also 
cretaceous rocks belonging to the Babiney Formation where there is continuous sedimentation of the Maastrichtian to the Paleocene with predominantly Siliciclastic, Siliciclasticcarbonated, and thiogenic composition: polymorphic sandstones of various granulometries that are interspersed with limolites, shales, conglomerates, and tuffs; There is also a considerable volume of carbonated rocks, limestones and loam, towards the upper part of the cut, of Paleogenic age. (Fig. 10).

On this tectono-stratigraphic unit and with a power of thousands of meters, is the Paleogenic volcanic arc, which occupies the heights of the Sierra Maestra and whose backup deposits extend through the regions located north of the eastern region, from the region from Holguin to Baracoa. This volcanic arc remained active until the lower part of the Middle Eocene, punctuated tumogenic and intrusive rocks that can extend to the Upper Eocene (Fm. Barrancas). These deposits were only cut in wells Manzanillo 1, Oruita 1, Embarcadero 1, Vicana 1, Vicana 2, Crescent $1 \mathrm{X}$ and Granma 1, this happens due to the depth of these wells that in some only reaches the rocks of the Oligocene or Middle Eocene. In the region between Babiney and Jiguaní, rocks of Eocene Lower Age (Formation. Jiguaní) appear, composed of limestones and marl with silicon lenses and chapels, which in the last maps made have been included as Round Puddle Formation [10] but because of their age and composition they do not belong to this unit.

In the Middle Eocene there is a stage of formation of carbonated and fragmentary-carbonated rocks of different sedimentation environments (Charco Redondo and Puerto Boniato Formations), (Vicana 1, Vicana 2, Creciente 1 $\mathrm{X}$, Macaca and media Luna).

The Granma 1 (Fig. 14), Creciente 1X (Fig. 13), Oruita 1 (Fig. 16), San Ramón 1 (Fig 15), Manzanillo 1, Santa Regina 1 (Fig. 17), Rio Tana 1, and Bayamo 1 wells) and at the end of the Middle Eocene there are two main types of deposits, thick fragmentary and siliciclastic. They are distributed irregularly on the northern slope of the western region of the Sierra Maestra and were cut at the Niquero 1 well (Farallón Grande Formation).

And in the Babiney region (Marión Formation). Fm. Marión emerges very well in the quarry near the town of Papi Lastre. In its lower and more powerful part, a conglomerate of blocks of up to $1 \mathrm{~m}$ appears. In the diameter of magmatic rocks, diabasas, gabros, tonsil basalts, sandstones, tuffs and limestones of different types, biogenic pink, white, cream. This poorly selected conglomerate has areas with small fragments and a greater amount of matrix of calcareous-clay composition. Within the conglomerates appear cream-colored calcarenites in $10-15 \mathrm{~cm}$ layers and yellowish marls.

This package of calcarenites and marls is interspersed between the conglomerates, above this sequence, conglomerates similar to the previous ones appear, with a clast size somewhat smaller although they can reach $50 \mathrm{~cm}$. with a more abundant carbonated-clay matrix. This conglomerate transitions to a thick yellowish-colored calcarenite, and at the top loops with isolated fragments.

The siliciclastic sediments, of Eocene Middle High-Upper Eocene age, emerge widely in the southern and eastern region of the basin, including the western region of the Sierra Maestra, whose representative is the San Luis Formation. It is notable that the characteristic rocky association of this unit both on the surface and in the wells drilled in the southern and southeastern part of the basin is only dated as Middle Eocene and extends only to the Upper Eocene only the rocks cut by the wells drilled in the center of the Basin like Granma 1, Embarcadero 1 and Bayamo 1 and in surface towards the east. The occurrence of a discordance that occupies the entire Upper Eocene is evident, and is clearly manifested in the Crescent 1, Manzanillo 1, El Oruita, 1, Vicana 1 and 2, and Crescent IX wells.
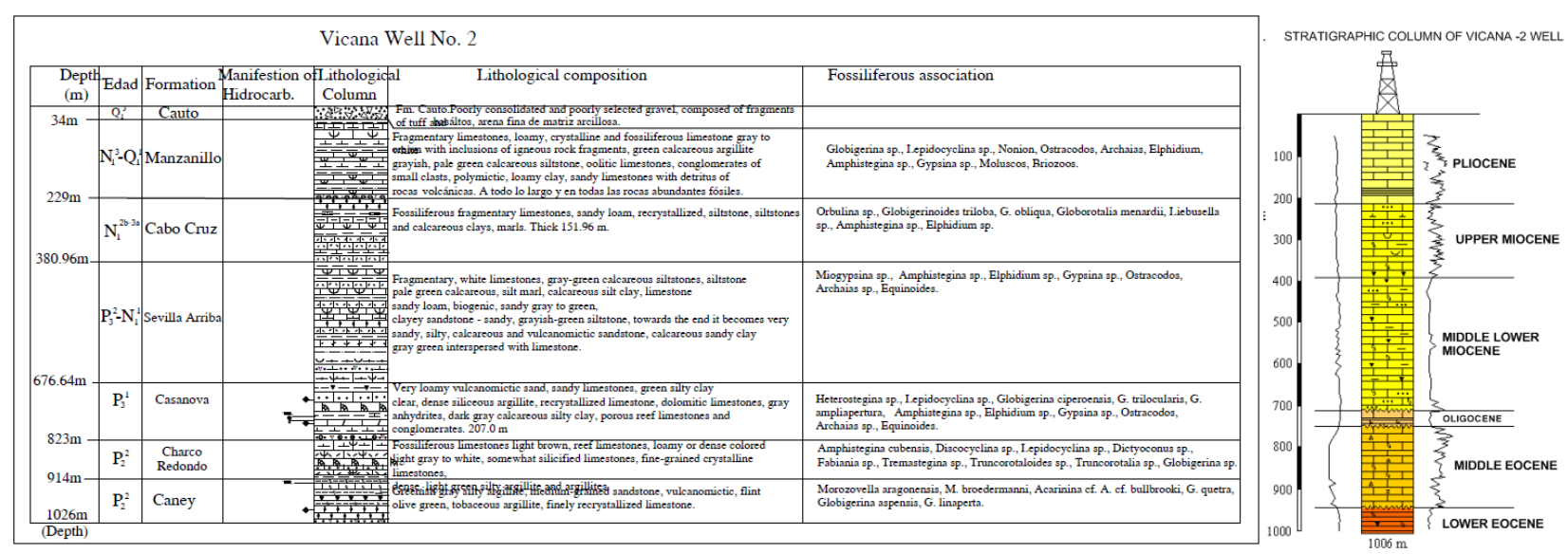

Fig. 11. Stratigraphic Column of Vicana Well No. 2 and its Lithological Compositions (Modified after [11]). 


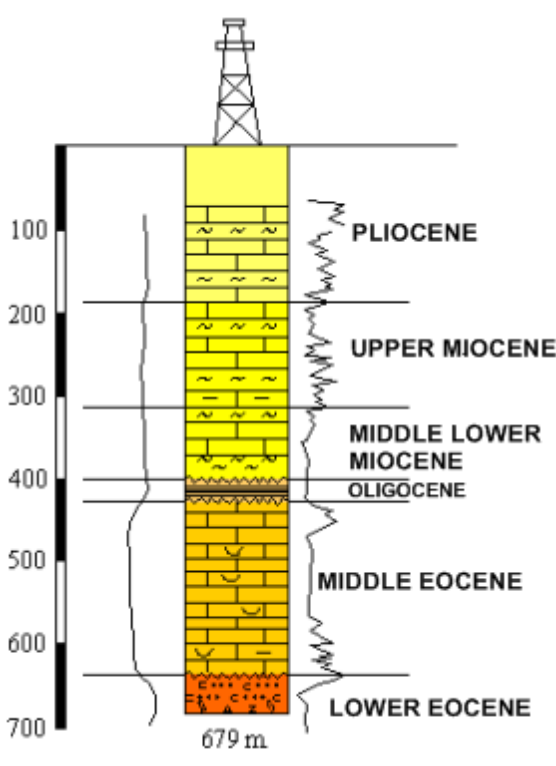

Fig. 12. Stratigraphic Column of Vicana Well No. 1 Modified after

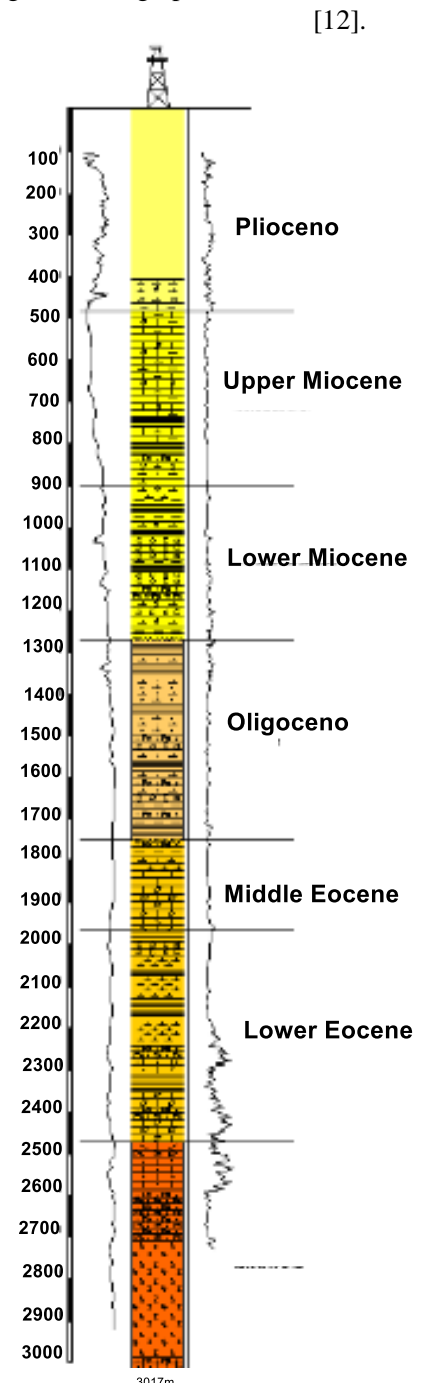

Fig. 14. Stratigraphic column of Granma I well [5].

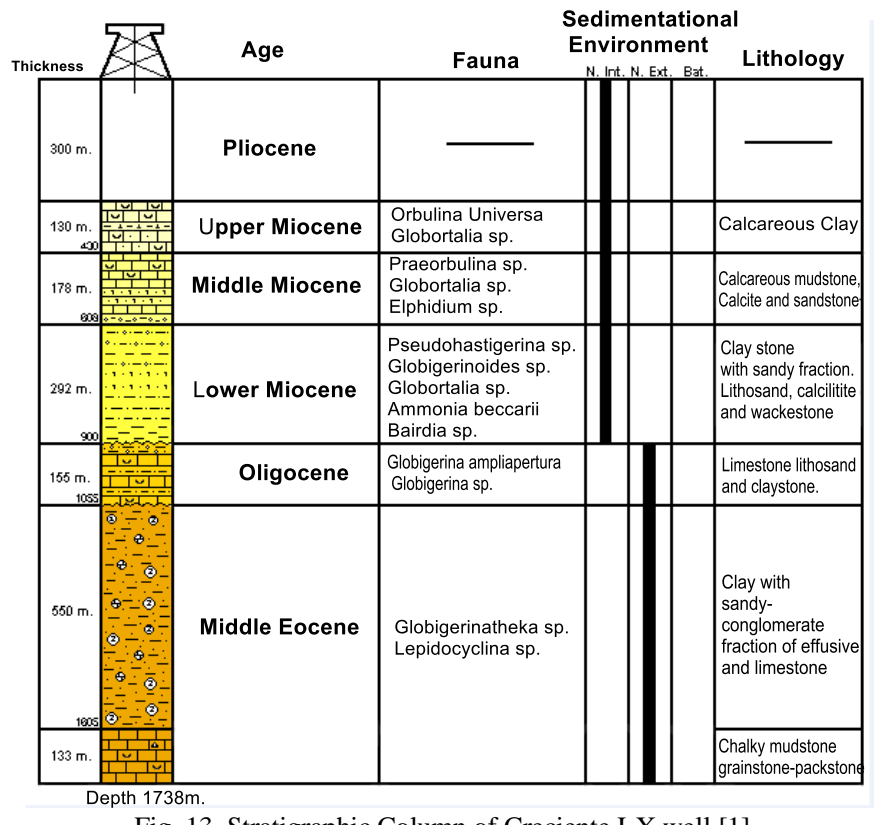

Fig. 13. Stratigraphic Column of Creciente I-X well [1].

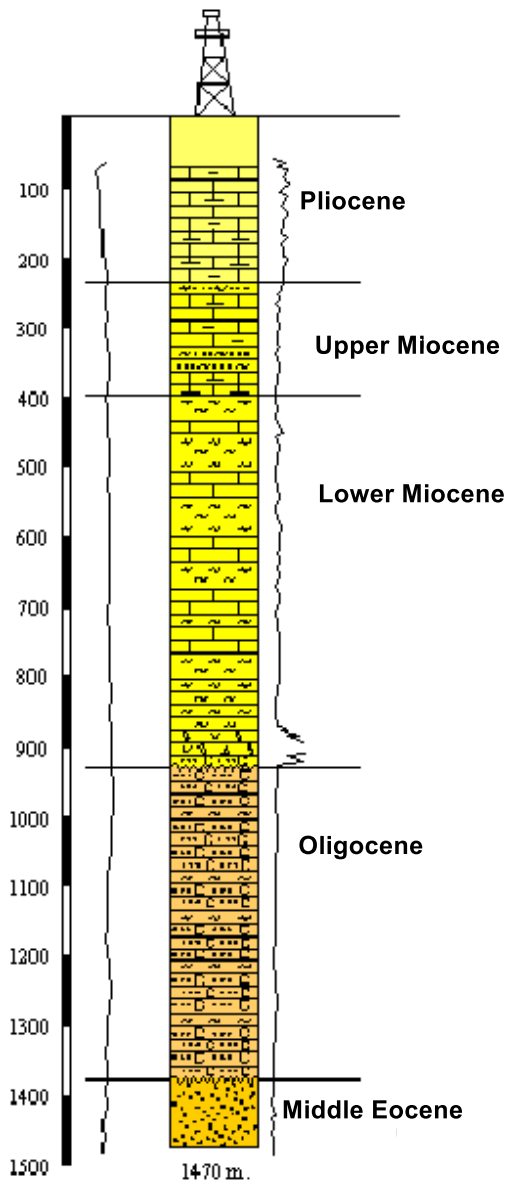

Fig. 15. Stratigraphic column of San Ramon I well [5].

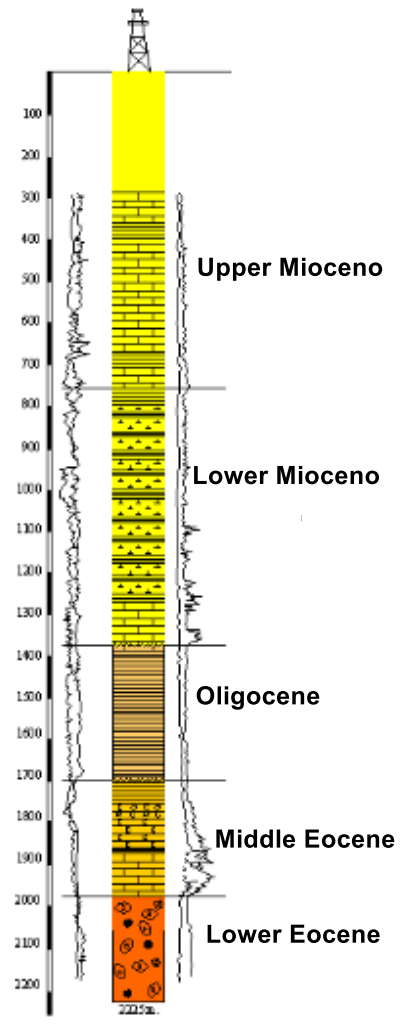

Fig. 16. Stratigraphic column of Oruita I well [9]. 


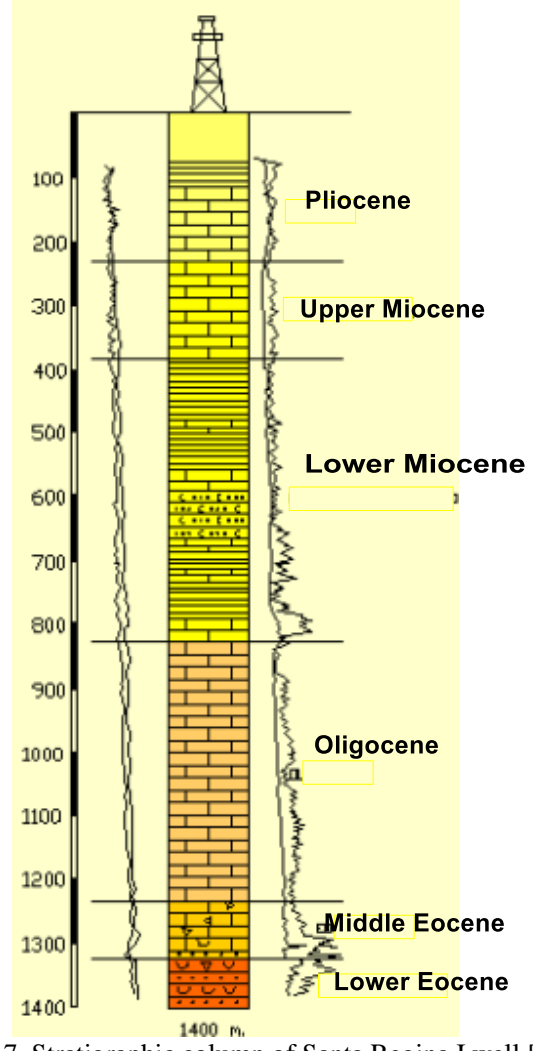

Fig. 17. Stratigraphic column of Santa Regina I well [9].

The greater thicknesses of the basin are formed by the packages of carbonated-clayey and fragmentary-carbonated rocks from Oligocene to Recent and that present frequent facial variations in short distances. The Lower Oligocene has few surface manifestations, but not in the wells where it appears cut in all of them (Macaca 1, Media Luna 1, San Ramón 1, Oruita 1, Santa Regina 1, Campechuela 1, Embarcadero 1, Granma 1; being absent in Manzanillo 1 and Crescent 1X wells, only small areas emerge around Babiney (Fm. Casanova).

From the Oligocene Superior, several lithostratigraphic units coexist that represent facial variations such as the Sevilla Arriba, Paso Real, Camazán formations, which occupy the largest extensions along with the Batiría Formation, also widely distributed. These units have continuous sedimentation to the Lower Miocene, and they pass from one to the other in short distances, manifesting a great facial variety.

The Miocene to Quaternary deposits occupies large thicknesses in the basin emerging in the southwestern extreme represented by the Manzanillo and Cabo Cruz formations, while in the rest of the region and in younger areas the youngest dates Datil, Bayamo and Cauto. In this period the sedimentation was in deltas.

\section{7) Tectonic structure according to seismic lines}

Base on the interpretations of the 8 seismic lines (Cub 20: 96-05; 96-06; 96-07; 96-08; 96-22; 96-09; 96-21 and 96-10.) (Fig. 19).

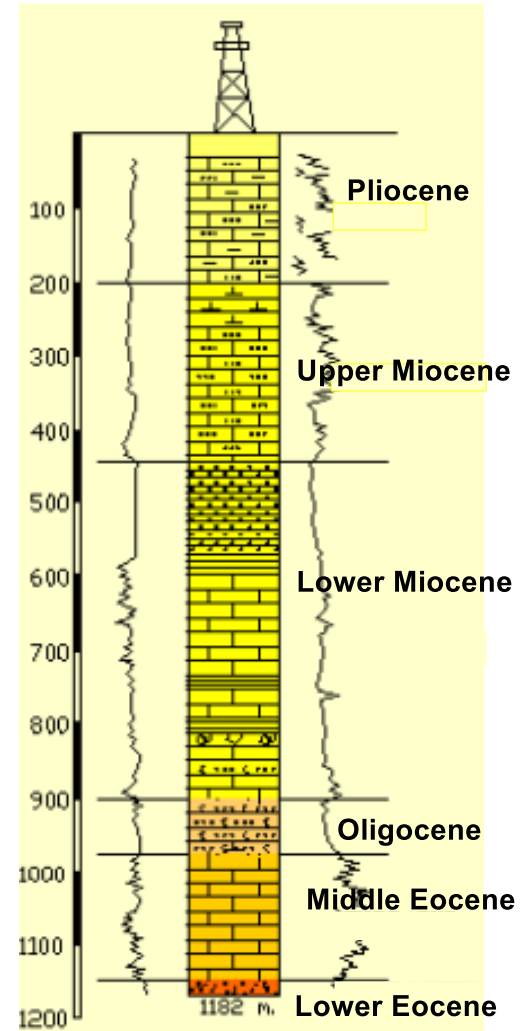

Fig. 18. Stratigraphic column of Macaca I well [9].

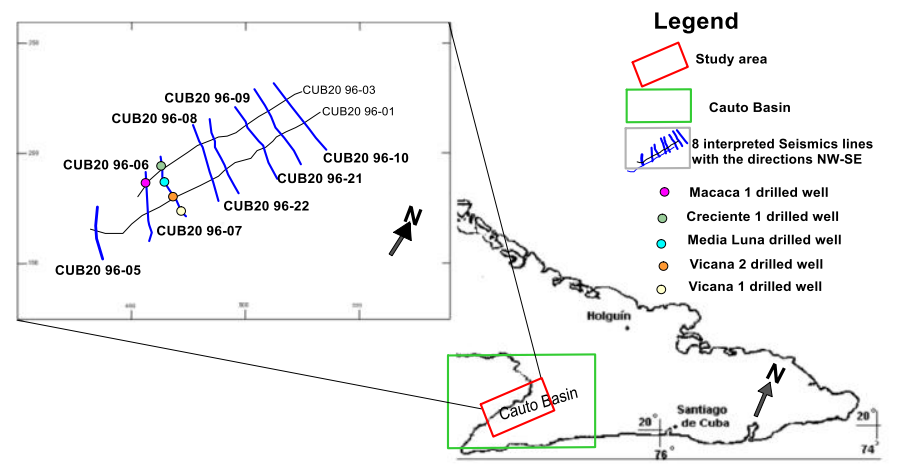

Fig. 19. Map of the location of Seismic lines and some of the drilled wells (Modified after [11]).

From the 8 interpreted seismic lines of the study area, it is observed that in the Basin there are important tectonic and sedimentary changes from the Eocene, reflected in the seismic sections interpreted from the Paleocene, the Upper Cretaceous Campanian-Maastrichtian, and other older ones.

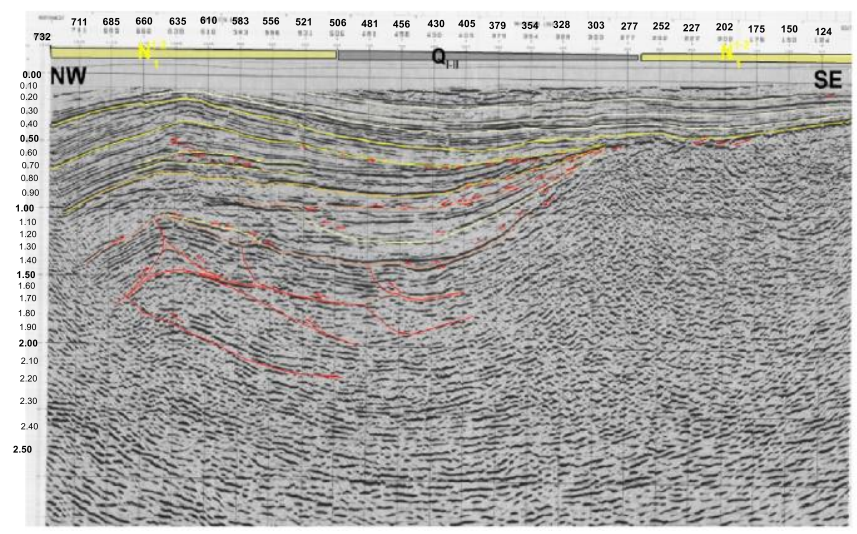

Fig. 20. Cub 20 96-09 seismic lines. 


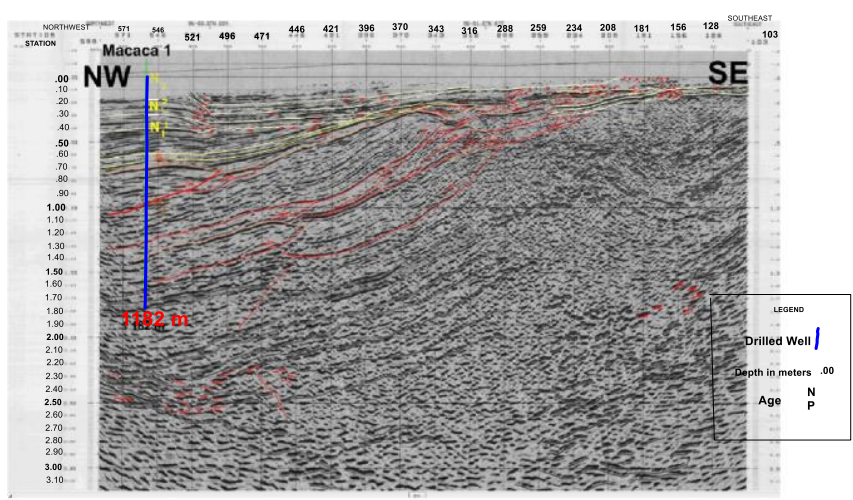

Fig. 21. Cub 20-96 06 seismic lines with the Macaca 1 well.

The basement of the Basin can be seen clearly in the seismic lines of references, a folded and ridged basement can be seen, composed of numerous flake folds, which generally, in their frontal part, fracture giving rise to smaller scales.

The interpretation shows that tectonic movements during Orogeny were extraordinarily strong, causing large stacks and other complex structures such as overlapping scaled structures.

The upper part of the basement of the Basin is known by some wells (Creciente 1x, Media Luna, Vicana 1 and 2 wells Fig. 22, which is constituted by rocks of the Lower and Middle Eocene $\mathrm{P}_{2}{ }^{1-2}$, Although rocks older than these have not been recognized, the geological survey works that have been carried out on the periphery of the Basin show the existence of rocks.

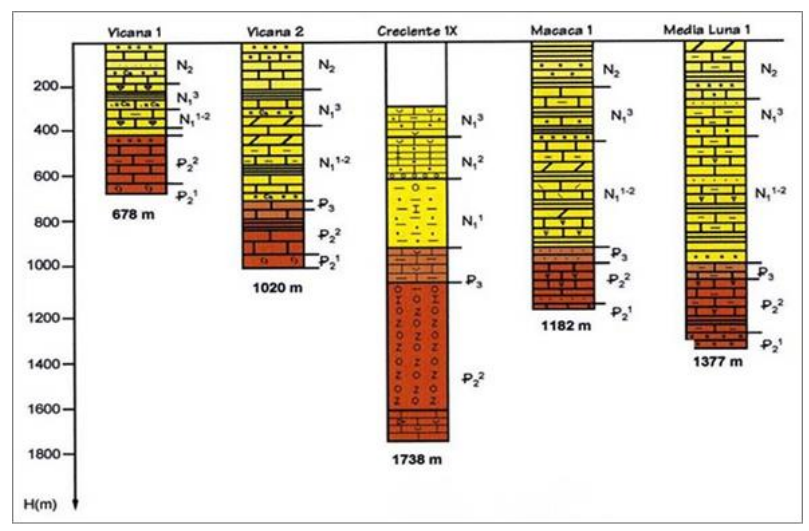

Fig. 22. Creciente 1x, Media Luna, Vicana 1 and 2 wells and their depth in metres $(\mathrm{m})$.

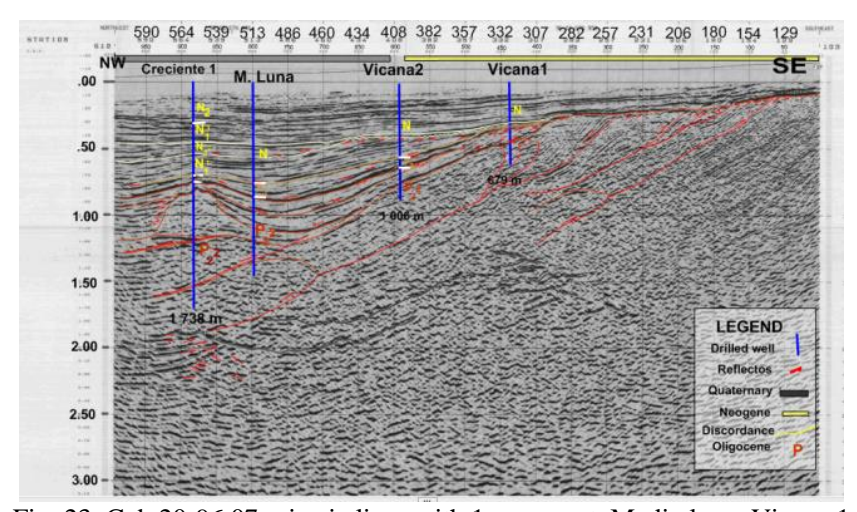

Fig. 23. Cub 20-96 07 seismic lines with $1 \mathrm{x}$ crescent, Media luna, Vicana 1 and 2 wells.

The research shows that strong Orogenic movements after the middle Eocene continued but weaker; however, the progress of the flake fold is clearly distinguished and how these movements have affected the rocks from the middle and upper Eocene to the Miocene.

\section{8) Stratigraphic sedimentary development of the basin}

The sedimentary style of the Eogenic sequence is the normal filling of the Basin which is evidenced by the shape of the reflectors that overlap against the surface of the Basement.

Similarly, the Oligocene sediments are deposited with a style of sedimentation similar to that of the Eogenic sequence or that of the normal filling (Fill Basin), these characteristics are manifested by the termination of the reflectors with Uplap structure In the basin areas, the Oligocenic rocks have important thicknesses as evidenced by the drilling of the Macaca well that cut more than $400 \mathrm{~m}$ of sediments; while towards the west of the study area the power of sediments of this age is reduced to a few tens of meters (Seismic section 96-07) (Fig. 24).

Stratigraphically, the sequences described above are followed by powerful Miocenic sequences, deposited from the Lower and Middle Miocene to the Upper Miocene which was cut by drilling wells. During this geological period in the basin, several deltaic sequences are observed with some periods of normal filling of the basin. The deltas studied deposited in the Miocene, and in the preceding epochs have been known for the behavior of the reflectors, which in their upper part and close to the strong contribution show truncations known as Uplap, and the lower part known as Downlap.

These elements show that the basin is characterized by intense erosion, transportation and deposition of sediments and slow subsidence, which allows us to clearly observe the magnitudes of the different deltas, more numerous towards the western part of the basin. In this area, there are clearly slope and background fans that show an intense process of erosion and abrupt transport of sediments, which are the product of the turbidity current.

These characteristics allow us to interpret that these sediments can constitute good quality reservoirs and be part of the trap. Nicholas [13] classifies Deltas according to their grain sizes in Delta top and Delta front where sediments reduce their size from gravels to clays.

The western seismic lines 96-07 (Fig. 24) and 96-22 (Fig. 25) show that delta structures have been deposited between the wells (Vicana 1 and 2) and others with normal sedimentation that shows a change in the sedimentation rate and subsidence of the Basin.

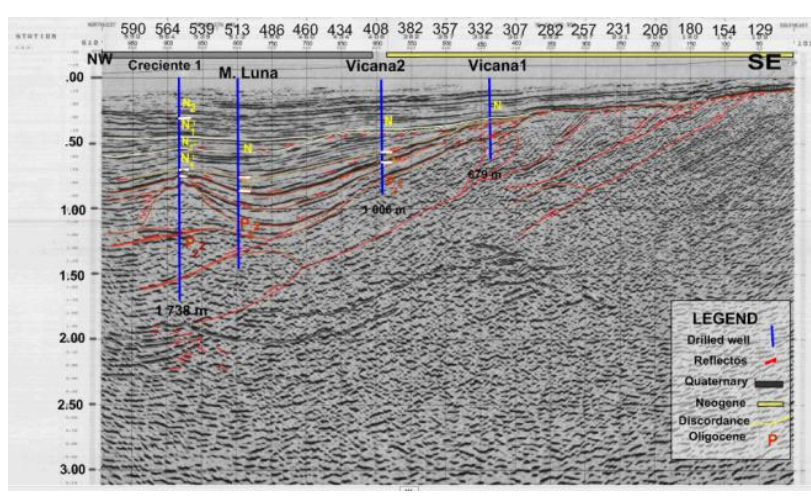

Fig. 24. Cub 20-96 07 seismic lines normal sedimentation from Upper Miocene. 


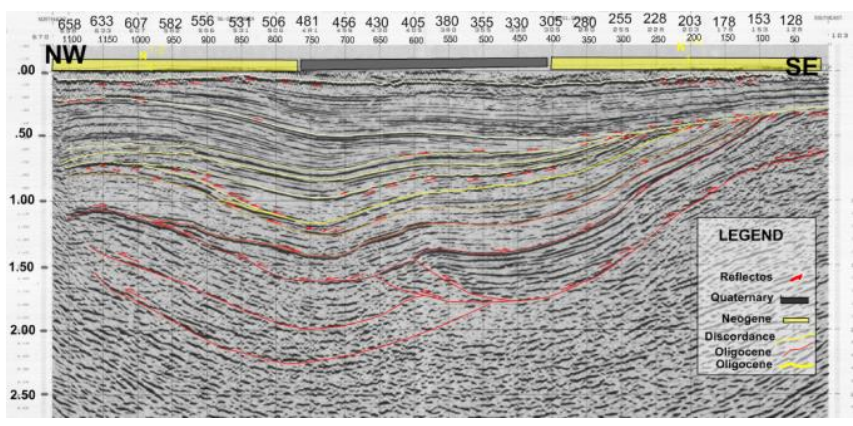

Fig. 25. Cub 20 96- 22 seismic line normal sedimentation from Upper Miocene.

During this geological period, it is distinguished that the most important source of contribution of the basin is located towards the southern portion, towards this part is the largest mountainous area of eastern Cuba, which in the rainy season and of strong storms manifest erosion and sedimentation more abrupt. Towards the western, most part of the study area, there is a predominance of gravitational deposits (bottom fan and slope) which indicates the existence of large rivers that moved abundant turbiditic material towards the bottom of the basins in different periods. In all seismic lines it is distinguished that the northern part of the Basin also provides sediments and sometimes abruptly due to the presence in the area of deltaic areas, although of a smaller magnitude than that observed to the south.

\section{9) Petroleum System in the Study Area Source Rock}

The surface geochemical researchess that has been developed in the Basin and its environs have not shown the existence of Total Organic Content (TOC) to become a source rock, constituting this aspect within the petroleum system the most limiting factor in the area. 6 wells have been drilled and there is no manifestation of hydrocarbons.

The interpretation of the seismic lines and their assessments shows the existence of numerous reservoirs made up of slope and bottom fans and several deltaic zones. All these reservoirs are overlaid by very clayey terrigenous sequences. Deltaic can be assessed as a good quality reservoir due to the accumulation of sandy fragments that allow the existence of good porosity and good interconnectivity.

In the fan of slope and bottom, as it is made up of turbiditic sediments that are deposited on the slopes and bottoms of the basins, in addition to this sedimentation occurring at high speeds, there is a poor selection of particles, characterized by porosity and high permeability.

\section{0) Seals}

For the forecast of the reservoirs and seals in the Basins it was necessary:

- To be characterized the sequences and traversed the drilled wells in the basin.

- Correlation of lithology, collecting properties and ages between them.

- Compilation of all petrophysical materials (records, and Data)

- Selection of the structures proposed by the seismic to execute the Interrelation of the study of the cores, well logs and seismic profiles.
The analysis of the Seal rock is carried out in the first instance by evaluating the seismic sections, the characteristics of the low acoustic impedance reflectors, typical of the clay-sand terrigenous sequences and also from the study of some nuclei in which the existence of very fine sandy rocks and clay material; and others described as shale (crescent well and Crescent1X) that can constitute excellent seals [11].

\section{1) Coverage}

The coverage of this basin is characterized by having small thicknesses where the rocks deposited are immature as well as the Organic Matter found in them. Therefore, the small coverage does not allow for a sufficient temperature to transform organic matter into hydrocarbons.

\section{2) Evaluation of the petroleum system}

In the study area, the existence of reservoirs considered acceptable and is well defined; and sealing sequences with acceptable quality. Both elements have shown the presence of mainly stratigraphic traps.

In the basement of the basin, numerous structures have been mapped made up of flaky folds of rocks from the Middle Eocene (Carbonate and terrigenous) that form structures with dimensions between medium to large and on them, terrigenous clay sequences are deposited, therefore they also constitute good traps.

\section{3) Loads}

Failure to demonstrate the existence of the source rocks and not finding hydrocarbons in the drilled wells or manifestations means that it cannot be demonstrated loaded. that the aforementioned traps may be.

\section{CONCLUSION}

1. In the Cauto Basin complex sedimentary processes occurred as a result of the very rapid sedimentation and slow subsidence, shown by the position of numerous deltaic areas, product of the intense erosion of the mountainous system and also important Slopes and Fans.

2. The presence of a discordance that occupies the entire Eocene-Superior is confirmed (Fig. 20, 21 and 25), both on the surface and in the Crescent 1, Vicana 1 and 2, and Creciente $1 \mathrm{X}$ wells of the southwestern region of the basin, while towards the center the Sedimentation was continuous during that time interval.

3. The discordance of the Upper Eocene extends to the Lower Oligocene represented in the Babiney region, where only sediments of this age were deposited in small areas, the Upper Oligocene lying directly and in disagreement on the Upper Eocene, that is, the Camazán Formations and Bitirí about the San Luís Formation.

4. Intervals were revealed that can be described as reservoirs as part of the background fans and deltaic areas.

5. Few hydrocarbon possibilities in the study area due to the limited manifestations of hydrocarbons and the negative results obtained when evaluating possible bed rocks. 


\section{RECOMMENDATION}

1. To carry out geochemical studies that aimed at detecting possible hydrocarbon-generating rocks, in addition to studying the processes associated with the migration and accumulation of hydrocarbons.

2. Deepen the correlation of sedimentary fill, to define seismic stratigraphic structures and surface geology.

3. To Increase the level of seismic investigations in the areas of interest in greater depth. And use geophysical technologies for studies to enhance the greater scope.

\section{ACKNOWLEDGMENT}

We acknowledged the Department of Geology, Instituto Superior Minero Metalurgico de Moa (Universidad de Moa), University of Moa, Holguin, Cuba for making this research possible, especially to Dr. Jesus Blanco Moreno that supervised and make availability of the data for this research, and to Dr. Habeeb Ayoola Ayinla for his revisions and advices.

I would also like to acknowledge my brothers love and caring; Dr, Laminu Kaumi and Dr. Mansur Salisu for their supports, thank you all may Allah SWT grant you with Aljannatul Firdausi (Ameen).

I can't forget you my colleague, friend, and my mentor Edidiong Ubuho who guides me and teaches me how to operates some basics and complex computer softwares.

Special thanks to Yuniela Diaz (Neki) you are also unforgettable and thank you for your maximum supports and prayers. Lastly to my beautiful wife (Ainau A.K. A Alma Gemela) who is carrying my unborn child, I do love you 'un monton'.

\section{CONFLICT OF INTEREST}

There is no conflict of interest by the authors to publicize.

\section{FUNDING}

No funding of any form was received for this research.

\section{REFERENCES}

[1] José V. C. Interpretación integrada de atributos geólogo - geofísicos para la selección de área perspectivas para la explotación gasopetrolíferas en la Cuenca Cauto. Tesis de la Maestría. ISPJ Cujae la Habana, 2011.

[2] García D; Toirac R; \& Otero R. Estratigrafía de la región de la Cuenca del Cauto y su correlación con el subsuelo. 2007.

[3] Aballí P. Reporte de la interpretación geólogo - geofísica de los trabajos sísmicos de la segunda etapa, en el bloque - 20. Empresa de Geofísica Digicupet. Ciudad de Habana, 1999.

[4] Miró G. Aplicación de los métodos geofísicos, morfometricos y de teledetección para el estudio de la Cuenca del Cauto. Geociencias. La Habana, ISPJAE, Facultad de Ingeniería Civil, Especialidad Geofísica, 1993.

[5] Álvarez J. C. Generalización geólogo - geofísico de los trabajos ejecutado en los bloques de Cuba Sur - Oriental 23 Sur, 22, V, VA, VI, VIA, VII, VIIA Y 20, 2001 b.

[6] Alarcón Y. N. Caracterización Tectono-estratigráfica de la Cuenca Cauto-Guacanayabo. Tesis de diploma ISMM MOA, Holguin Cuba, 2008 .

[7] Sokolova E. A., Brito A. y Coutin D. P. Formación manganesífera Cobre (provincia Oriente, Cuba), en Geología de los yacimientos minerales de Cuba. Moscú, 1975.
[8] Cobiella J. Estratigrafía y paleogeografía del paleógeno en Cuba Oriental. 160 págs. Instituto Superior Minero Metalúrgico de Moa, (Universidad de Moa), Holguín, Cuba. (Tesis doctoral), 1978.

[9] Santiesteban D. Ubicación de estructuras favorables para la acumulación de hidrocarburos en la parte central de la Cuenca Cauto, a partir de la interpretación sísmica y datos de pozos. Trabajo de Diploma, ISMM, (Universidad de Moa) Moa, Holguin, Cuba, 2011.

[10] Nagy E.; Brezsnyanszky K.; Brito A.; Coutin D.P.; Formell F.; Franco G.L.; Gyarmatti P.; Jakus P. y Radocz G.Y. Texto Explicativo del Mapa Geológico de la provincia Oriente a escala 1; 250000 levantado y confeccionado por la Brigada Cubano-Húngara entre 1972-1976. Inst. Geología y Paleontología, Academia de Ciencias de Cuba, 1976.

[11] Aminu B. M. Evaluación de la parte Suroeste de la Cuenca Cauto y sus posibilidades gasopetrolíferas. Tesis de diploma. ISMM Moa Holguín, 2011

[12] Moses Angula T.K. Evolución tectono - estratigráfica de la Cuenca Cauto, según modelo de sistema de Cuenca de antepaís, 2012.

[13] Nichols G. Sedimentology and Stratigraphy. A John Wiley \& Sons, Ltd., Publication, 2009.

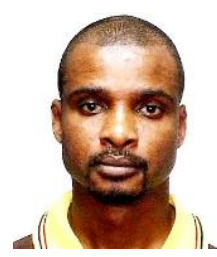

Mu'awiya Baba Aminu was born $1^{\text {st }}$ October 1982 in Bauchi, Bauchi State, Nigeria.

$\mathrm{He}$ is M.Sc. in Prospection and Exploration for Oil and Gas Fields at Instituto Superior Minero Metalurgico de Moa, (University of Moa) Holguin Cuba, 2012, B.Eng. Bachelor in Geological Engineering, Instituto Superior Minero Metalurgico de Moa, (University of Moa) Holguin Cuba, 2011, lecturer in the Department of Geology, Faculty of Science, Federal University Lokoja, Kogi State, Nigeria, member of Professional Body: Society of Cuban Geology (SCG), Cuba. 